\title{
The Case for a TLD for Wales
}

\author{
Iolo Madoc-Jones*
}

North East Wales Institute of Higher Education, School of Health, Social Care, Sports and Exercise Sciences, Plas Coch campus, Mold Road, Wrecsam, LL11 2AW, UK

\begin{abstract}
This article explores the rationales for creating specific top level domain (TLD) names to support minority languages and cultures, focussing specifically on the case for a TLD .cy or .cym for Wales. Some background information on domain names and Wales and the Welsh language is provided. Following on from this, the way identity may be constructed is explored and the importance of TLD's in terms of enabling individuals to perform their identity is highlighted. The issues that arise with using the current .uk TLD in Wales is explored. Finally the rationale for a .cym TLD for Wales as opposed to any other is considered.
\end{abstract}

\section{THE CASE FOR A TLD FOR WALES}

Over the last few years a number of campaigns have sought to establish top level domain (TLD) names on the internet for the use of particular minority groups. Examples include the campaign run by puntCAT to establish a cat TLD for the Catalan language and culture and the campaign run by dotCYM to establish a .cym TLD for the Welsh language and Culture. In September 2005, and as the result of a long campaign by puntCat activists, ICANN approved the first top-level domain to be dedicated to a particular language and culture when it registered the .cat sponsored TLD name for the Catalan community (Atkinson, 2006). According to Gerrand (2006) it came into being only after considerable political wrangling within Spain, Catalonia and the ICANN. That such a campaign was thought worthwhile will be baffling to many internet users. According to Edwards (1994) most majority language speakers remain unconvinced of the desirability of officially-supported minority cultural and linguistic programmes. This article explores the rationale behind such campaigns, focussing specifically on the rationale behind establishing a TLD for Wales. It begins with a brief outline of what domain names are and how they are allocated. Next, some background on Wales and the Welsh language is provided. Following on from this, the various debates concerning the significance of a domain name to a minority groups and culture are explored. How identity is performed and achieved and a domain name may be significant in this process is foregrounded. The problems that arise with using the current .uk TLD in Wales is then explored and finally the rationale for adopting a g-TLD for Wales such as .cym, as opposed to any other g-TLD is considered.

\section{TOP LEVEL DOMAIN NAMES}

Every computer on the Internet has a unique address called its Internet Protocol address and it comes either in the

*Address correspondence to this author at the North East Wales Institute of Higher Education, School of Health, Social Care, Sports and Exercise Sciences, Plas Coch campus, Mold Road, Wrecsam, LL11 2AW, UK;

Tel: 00441978 290666; E-mail: jonesim@newi.ac.uk form of 32 binary digits (bits) written as a four part dotted decimal such as 207.151.159.3 or, more recently, 128 bits written as 32 hexadecimal digits such as 2001:0db8:0000:0000:0000:0000:1428:57ab. A non-profit making independent international body called The Internet Corporation for Assigned Numbers and Names (ICANN) manages these addresses through the Domian Name System (DNS). The DNS makes using the internet easier by allowing a familiar string of letters to be used instead of a numerical code. Part of the work of the ICANN is ensuring that all users of the internet can find a unique, valid and meaningful IP address and mnemonic to use so that internet users may surf the web and communicate with one another.

There are two main types of domain names. Country code top level domains (cc-TLD) are two letter country codes e.g. .uk, .us, based, since 1984, upon a list of country codes (ISO-3166-1) established by ISO, an organisation founded in 1947 to produce and co-ordinate world-wide industrial and commercial standards. To be listed in the ISO country code a country must either be a member of the United Nations, a member of any UN specialised agency or party to the statute of the International Court of Justice. Some cc-TLD pre-date this requirement. Hence whilst the country code for the UK in ISO-3166-1 is GB, .uk continues to be used as the country code for the UK. Seven other country codes also exist which are not aligned with the ISO3166-1 codes. However once established, the power to grant permission to use a particular cc-TLD's is often devolved to the country involved. Hence in the UK for example, Nominet registers domain names using the .uk cc-TLD (www.nominet.org.uk).

Generic top level domain names (g-TLD) on the other hand are primarily three or four letter codes which are used by a particular class of organizations e.g .com (for company), .org (for organisations) or .net (for network groups). They are limited in number and whilst some g-TLD are not restricted in terms of their use and are hence termed unsponsored, others, such as .aero used by the aeronautical industry, .mil used by the military and .museu used by museums are sponsored and thereby backed by a community which holds the power to decide whether a body can register 
a domain in that name. The terms and conditions under which this power is exercised are defined by ICANN.

The number of cc-TLD and g-TLD has increased over the last few years but remains tightly controlled by ICANN. This is because a cc-TLD must be related to an ISO-3166-1 country and a new g-TLD must be backed by a sufficient number of people to make its creation viable. Because the DNS is organized hierarchically however non nation groups and other bodies may establish second level domain names emanating from a TLD. Hence, to take Wales or the Welsh language (Cymru and Cymraeg respectively in the Welsh language) as an example www.Cymru.co.uk, www.cymru.com, www.cymraeg.net may, and do, exist; but because Wales does not appear on ISO-3166-1 and activists have failed so far to persuade ICANN that a g-TLD for Wales is viable, www.cymraeg.cm for example or a www.cymru.cym do not.

The newly established .cat is a sponsored generic top level domain name presently managed by the puntCAT foundation within Catalonia and is intended to serve the needs of the linguistic and cultural community of Catalonia (Jobins, 2006) According to Gerrand (2006) puntCAT initially aimed to establish .ct as the cc-TLD for Catalonia but this met with considerable opposition from those who were concerned that it gave impetus to those seeking Catalan succession from Spain. PuntCat therefore changed its aims to establishing a .cat g-TLD. The .cat g-TLD was established in 2005 with the support of the Spanish Government and partly on the basis that the linguistic population that spoke Catalan, and might therefore use the .cat TLD, was over one million world wide. Equally on the basis that the Catalan language and culture was not addressed by a single Spainish .sp ccTLD (Atkinson, 2006; Jobins, 2006).

The success of puntCAT in getting a TLD created has given impetus to groups seeking similar domain names in other countries. This article considers the rationale behind such campaigns drawing on the situation in Wales. The aim of establishing a TLD in Wales has recently attracted political support in Wales. The Labour/ Plaid Cymru coalition in charge at the National Assembly in Wales since 2007 have pledged its support for such a TLD. Some of the rationale behind the desire to have such a TLD for Wales is explored next, necessitating an exploration of Wales and of national identity in Wales.

\section{Wales and the Welsh Language}

Hourigan (Hourigan, 2001) arues that people in Wales retain a "highly developed sense of nationhood linked to the language" (p.83). Drakeford and Williams (Drakeford, M., \& Williams, 2001) contend that consideration of the Welsh language is central in any discussion of national identity in Wales. A survey commissioned by the Welsh language board suggested that in $200089 \%$ of Welsh people (Welsh and English speaking) considered that the Welsh language was important for the Welsh national identity (Bwrdd yr Iaith Beaufort Report, 2000). According to the Welsh Language Board.

"The Welsh language has a special place in our history because it is one of the major factors which has made us what we are...few would deny that Welsh has played an important part in the formation of our national identity ( 7 p.1).

The 2001 census identified that around 550,000 people in Wales described themselves as having ability in the Welsh language. $21.8 \%$ of the Welsh population therefore speaks Welsh. On a global level, because of the number of speakers, Welsh is in the in the top 1000 of the worlds 6000 or so spoken languages. (Crystal, 2000; Krauss, 1995). This prominent position in the world ranking suggests the Welsh language is in a strong position. Returns from census over the last two centuries however suggest that the proportion of Welsh speakers in Wales has been in decline. In $180180 \%$ of the population could speak Welsh. By 1851 this has reduced to $67 \%$. According to the 1901 census $50 \%$ of the population of Wales reported having some ability in the Welsh language. By 1911 this figure had dropped to $43.5 \%$ and by 1991 to $18.7 \%$. Despite this, compared to the 1991 Census, and to all other indigenous minority languages in the UK, the 2001 census showed an increase in Welsh speakers up from $18.7 \%$ to $20.5 \%$ of the population. A language use survey conducted by the Welsh Assembly Government suggested that by 2004 the figure was $21.7 \%$ (Iaith pawb and Welsh Language Scheme Annual Report 2005-2006).

\section{LANGUAGE VITALITY}

Accounts exist which would seek to explain the continued vitality of the Welsh language in Wales with reference to its essentiality in identity. Burr (Burr,1995) identifies the seventeenth century as a time of rapid social, industrial and political change involving a philosophical drift towards the view of the world as a place of laws, order and logic. As part of this Woodward (Woodward, 2002) argues that classificatory systems were developed to explain human variations. Some, like Freud's focussed on personality types, others, such as those that divided the human population according to skin colour, focussed on population types. According to Gellner (1983) and Kedourie (1960) classification schemes also developed based on the idea that humanity was naturally divided into nations, and that nations could be known by certain characteristics, one of which was language.

The idea that language was an essential element in defining nations developed from the eighteenth century onwards. Herder, for example, in the late eighteenth century argued that it is the possession of its own distinctive language that constitutes the touchstone of a people or Volk, the sine qua non of its national identity and spirit (in 15, p.173)

This concept of linguistic determination was explored further by Vygotsky (1972) and Whorf (1956) who suggested that the structure of a particular language influences the way that speakers of that language know themselves and understand the world around them. He suggested that each language has what in German is termed Sprachgefuhl or 'speech feeling', that directs its speakers towards a particular way of thinking about the world and their place within it. According to Sapir (1929) no two languages were ever sufficiently similar to be considered as representing the same social reality and the worlds in which different societies live were distinct worlds "not merely the same world with different labels attached" ( p. 207). 
More recently however such static essentialist conceptualisations of a nation and national identity have been rejected (Blackledge \& Pavlenko, 2001). Essentialist accounts of nations and identity have either given way to political theories which understand that identities are created as a by-product of economic or material conditions or to more ethnographically orientate sociolinguistic theories which focus on the way identities are flexible, constructed in linguistic interactions and are then reified as essential.

Developing a political theory, Gellner (1983) argues that nations are products of the modern era and specifically the economic changes associated with industrialisation. He argues that industrialisation prompted the need for a new type of central state which would need to ensure the 'homogenous branding of its flock" (p.140). This was because a capitalist economy required that land be appropriated and then bounded and that a singularly literate and mobile workforce be developed who could work effectively together in large urban settings.

Critics of such political theories attack the 'structuralism' inherent within the accounts and the way the role of human agency in creating and sustaining group identities is underplayed. As a result, authors such as Barth (1969) develop sociolinguistic accounts of national identity which conceives of such an identity as established in social settings as individuals interact with each other and when creating such identities is useful. According to Barth (1969), part of the process of ethnic or national group identity formation in particular involves the creation of a boundary to separate those within the group from those outside of it. This boundary forming function can be fulfilled by racial, religious, territorial or linguistic differences. According to Borland et al (Borland, Fevre, \& Denny, 1992) these differences are then reified as natural...

Attempts are made to define the criterion of inclusion and exclusion empirically and to claim that these distinctions are 'natural' and the groups so defined come about by natural means (p.52)

In relation to ethnic group or nation identity formation, Renan (1990) has observed that forming such a group involves not only the adoption of a boundary marker, but, the invention of a tradition and the creation of a supportive history to underpin claims to nationhood. Griffiths (1994) highlights how in the Welsh context, for example, Eisteddfodau and the ceremony and paganistic rituals of the Gorsedd are imagined as directly descended from bardic assemblies when they can be dated back only as far as 1858 . In a similar vein Trevor-Roper (1983) highlight how Scottish national dress, as codified in clan tartans are inventions of the same era. Such inventions allow for the creation of what Anderson (1983) calls the "imagined communities" in question.

Authors such as Worsley (1984) have criticised Barth however for over-emphasising the role of instrumental choice in the formation of ethnic or national groups and for his 'anything goes' ontology. Hechter (1975) and Worsley (1984) contend that Barth underplayed the external historical social and political constraints which might also play a part in giving rise to and sustaining such identities. Hence according to Anderson (1983) national consciousness can arise historically only when substantial groups of people are in a position to think of themselves as living parallel lives to others. Williams (1985) and Robbins (2001) argue Welsh people and Welsh speakers probably had little sense of themselves as a national or ethnic group until the process of 'othering', occasioned by the Statute of Wales Act in 1536, created the possibility for them to conceive of themselves as a group. Then and over the centuries, Wales was so completely colonised and assimilated as part of England, the ability to speak Welsh probably became one of the main attributes available as a marker of a separate identity in Wales (Jenkins, 1997). This is dissimilar to the Scottish situation which maintained governmental and administrative structures separate from England even after unification in 1707. It is possible that it is because of the presence of other markers of identity in Scotland that Scottish Gaelic has not survived as well as the Welsh language in Wales.

May (2001) and Bishop, et al. (2003) seek to synthesise political and sociolinguistic theories to stress the enduring historical and the recurring constructed ness of identity. They extend Bourideu's (1977) concept of habitus to argue that identities need to be understood as enduring social, political and cultural forms of life, into which individuals are born. From this perspective, when people refer to their identity they are referring to a way of life and something which is concrete and outside of themselves and which predates them. In a similar vein Fishman (1997) argues that a detached view of language, as simply a fairly arbitrary border guard which is reinvested with power by every generation, ignores the extent to which language can become the basis for shared existence and life patterns based on the historical influences on a hermetically bounded language group and its speakers.

Accordingly Bishop, et al. (2003) and Coupland, et al. (2005) argue that identity in Wales encompasses the three dimensions of subjectivity, knowledge and practice or feeling, knowing and doing. Subjectivity for them is the feelings of allegiance and personal commitment an individual has to a group. Knowledge refers to the information that may underpin a social identity and the awareness of differences Practice refers to activities in social domains where social identities are realised. Whilst some diasaporic Welsh identities may be based on knowledge of Wales alone, or feelings of belonging, according to Coupland, et al. (2005) and Bishop, et al. (2003) the three aspects of knowing, feeling and doing capture the lived experience of being a member of a social or ethnic group.

\section{AFFIRMING A WELSH LANGUAGE BASED IDEN- TITY}

It is in relation to the importance of the knowing, feeling and doing of identity that the importance of the Welsh language in Wales and a campaign for a Welsh TLD may be located. By using a Welsh TLD it is argued that a person may see expressed and validated their national identity and some sense of their self. They will be given the opportunity to perform and thereby recreate their identity. For Billing (1995) identity is achieved through the performance of a series of small scale acts. In "Banal nationalism" he outlines his view that identity is achieved through the completion of banal, routine, day to day activity such as in the use of coins, stamps, flags, language or the singing of songs. Hobsbawm and Ranger (1993) also refer to such activities as central in 
reproducing identity and draw attention to the way symbols can come to be used as "badges of membership" (p.11).

Developing his theory further Billing (1995) argues that identities can be oppressed through small scale banal activities. His account of the accomplishment of domination has resonance with Bourdieu's (1977) account of "symbolic power" by which he means the power of certain groups to maintain control over others by establishing their view of reality and their cultural practices as the most valued and, perhaps more importantly, as the norm. Heller (1982) refers to the micro-processes of symbolic domination, that is the way grand domination is supported and effected by the everyday micro actions of individuals and organisations- for instance through the use of a specific word or language. The absence of a TLD for Wales may in some sense appear trivial. Bourdieu (1991) however suggests that the trivial is important and that the social world is embodied by people at the level of habitus and they reproduce it without thinking about its meaning.

In terms of supporting spoilt or compromised linguistic identities, Nelde (2000) argues that the most important indicators of the longer term health of a minority language are the extent to which it is legitimated and institutionalised within the civic institutions of a nation-state. Giles et al. (1977) agree that language vitality is related to issues of demography (number of speakers and their concentration), the status of a language (its value in economic, social and political terms) and the institutional support it enjoys (the agencies that support the language and wherein it is used). A key issue therefore in terms of the continued vitality of a minority language is whether it is has status and is seen, heard and used.

\section{WHAT ABOUT .UK}

The same sense of affirmation or sense of national and personal validation may not derive in Wales from using the existing .uk TLD. According to May (2001) up to the eighteenth century, the feudal, dynastic and largely agrarian societies that existed had little notion of national sentiment. The classic state was a multi-ethnic and multi-lingual empire. Creating llegitimacy for a new kind of state was a key concern for British liberal philosophers of the eighteenth century. Drawing on the early ideas of Thomas Hobbes (1588-1679), Locke (1632-1704) and Rouseau (1712-1778) John Stuart Mill (1806-1973) argued that a strong state could be created and endowed with legitimacy if a civic national identity cold be established (May, 2001). In the UK this would be in terms of the British citizen or citizen of the UK.

According to Rex (1996) until fairly recently nationstates did not reflect much on the issue of national identity. However, a number of authors have recently considered the civic identity that nation-states came to promote, and have suggested that the civic identity was not neutral but promoted a particular ethnic group's interests. As Kymlika and Patten (2003) note, no matter how much a liberally orientated state would wish to stand above various ethnic groups and nationalities it must of necessity do so in one language or another. By adopting a state language, the state (in effect and by default) accords some positive rights and higher status to members of the majority language group. According to May (2001), notwithstanding a concern with establishing a neutral state, some of the early nineteenth century liberal writers accepted that some ethnicities would come to prominence over others. Mill for example wrote: nobody can suppose that it is not beneficial to a Breton...to be brought into the current of the ideas and feelings of a highly civilised and cultivated people (45, p.395).

According to May (2001) and Bourdieu (1977) the concerns and language of majority ethnic groups came to be embodied in formal state structures. Blackledge (2002) argues that promoting one language was central to establishing an ethnic groups supremacy because "its symbolic status occurs within the larger process of imagining the nation" (p.199). According to Dunbar (1996) promoting one particular language evolved as an ultra efficient way of grooming allegiances to a particular identity.

May (2001) argues that thereafter expressions of ethnicity came to be regarded as regressive and inherently destabilising. He argues that concerns about the destabilising potential of ethnicity within the newly formed nation-states provided impetus to attempts to assimilate some ethnic minority communities, sometimes violently, into the civic collective. Histories of the Welsh and Welsh language and people do not record instances of the type of brutal linguistic oppression associated against linguistic and cultural minorities in Canada, the USA and Australia. Nonetheless, a number of authors have explored the Welsh context and have argued that the Welsh language and Welsh identity has been in decline over the last 600 years because state policies have either overtly marginalised or made no provision for Welsh speakers and Welsh communities (Alcoff, 1997; Brown, 1995; Connolly, 2002; Kidd, 2002; Pugh \& Jones, 1999; Davies, 1994; Jackson, 1994; Russell, 1995; Matonis \& Melia, 1990; Ball, 1993). The exclusion of the Welsh language from the school curriculum in Wales from 1870 onwards is accorded particular significance in many accounts of the Welsh language This exclusion followed from the 'Report of the 1847 Commissioners of Inquiry into the State of Education in Wales' (Commissioners of Inquiry into the State of Education in Wales, 1847) in which it was stated:

The Welsh Language is a vast drawback to Wales and a manifold barrier to the moral progress and commercial prosperity of its people. It is not easy to over-estimate its evil effects. (p. 66).

The subsequent 1870 Education Act made no provision for the teaching of Welsh in Wales. In some Welsh schools, children caught speaking Welsh were required to wear a piece of wood with 'Welsh Not' inscribed upon it. The child left wearing at the end of the day would be punished. Monolingual educational policies were promoted and supported by research into bilingualism which suggested that bilingualism had deleterious effects on a child's cognitive, linguistic and emotional development (Anastasi \& Cordova, 1953; Bossard, 1945; Smith, 1939; Spoerl, 1943; Yoshioka, 1929). Robbins (2001) argues that in the processes of nation state building Wales was relegated to a footnote in British history. The entry in the early editions of the Encyclopaedia Britannica "For Wales- see England" is often used as an illustration of this marginalisation of Wales. As a result, according to Williams an 'internal colonisation' thesis has been "accepted and embraced" in Wales (66 p. 79). According to this thesis, Wales has been socially and 
economically marginalised within the UK, anglicised by the English, and a distinctive Welsh cultural identity and/or language is under threat.

McCrone and Kiely (2000) argue that, as a result, contemporarily the non-English peoples of the British state, The Scots, Welsh, Cornish for example, would be more likely to treat nationality and citizenship as different orders of concept. For this reason the all-encompassing .uk tLD might be problematic for not speaking to the sense of nationhood certain groups in the UK embrace. McCrone and Kiely (2000) suggest that whilst $85 \%$ of the population of the $\mathrm{UK}$, if asked, would probably identify themselves as British citizens, for $15 \%$, of the population such an identification would be problematic. In support of this the General Household Survey of 2001 found that people in England were more likely to describe themselves as British (48\%) than those in Scotland $(27 \%)$ or Wales (35\%). Marwick (1996) using the results of a 1994 ICM/Rowntree Trust poll, shows that among the three nations of Great Britain the sense of British identity was strongest among the English people surveyed. Conversely, and to be expected, when these same people were asked about being English they demonstrated a weaker sense of being specifically English than did the Welsh respondents of being Welsh or the Scots of being Scottish. According to Williams (1999), Welshness and Britishness do not coalesce in quite the same way as Englishness and Britishness.

\section{TOWARDS A .CYM G-TLD}

The rationale for a cym g-TLD as opposed to .wal or a similar label is largely based around a cultural and language rights argument which starts from the premise that the Welsh language occupies a distinct place in the cultural and natural ecology of Wales. Speaking Welsh is not something everyone in Wales 'can do', and as Howe (1994) and Bleiker (2001) point out, the cultural context within which identities are now considered is post modernity. In contemporary Wales therefore supporting and attending Welsh rugby games, living in Wales, having parents born in Wales, attending church or knowing about Wales may all be associated with Welsh culture and feelings of national identity. However the Welsh language is something everyone in Wales can feel and know about and as research has indicated, its a strong symbol of identity in Wales. It is ascribed a status that is different from the status granted to other languages in Wales. Recent migrated languages are in the minority due to the relative numbers of speakers that happen to have migrated into Wales and these languages are often spoken by a sizeable population outside of Wales. The Welsh language however is understood as being in the minority as a result of colonisation and deliberate promotion of a majority culture and language. It is a language not spoken by sizeable communities outside of Wales. The Welsh language is therefore understood as singularly in danger of dying out because it is in a diglossic situation in Wales. In much the same way as attempts are made to save species that have become endangered as a result of the activities of human beings, the language rights argument holds that indigenous minority languages should be protected and efforts should be made to restore languages to their natural place in the linguistic landscape. According to Edwards (2001) a central assumption of this perceptive is that linguistic diversity is a good thing, and "the essential articles of faith that underpin modern ecological expression rest upon perceptions of morality and aesthetic preference"'(p.233). Promotional policies from this perspective would seek to normalise a language and institutionalise its use in society and part of this process would be through the 'banalities' (Anderson, 1983) such as the establishment of a TLD for Wales.

\section{THE CONTEMPORARY CONTEXT OF THE TLD FOR WALES CAMPAIGN}

The growing demand for a TLD for Wales finds expression at a time when recent developments in terms of global communication technology, mass population movements, economic globalisation, and the affordability of travel further complicate identity issues. Globalisation in particular may have presented particular challenges to nations and ethnic groups like the Welsh because they increasingly expose such countries to American cultural norms and the English language. American based multinational conglomerates control large international markets and media outputs, and one-third of the world's population use English in one form or another (Fishman, 2000). According to Kachru (1996) for every one native speaker of English there are four non-native speakers, meaning that the English language is fast becoming the lingua franca in multilingual contexts across the globe. According to Guinovart (2003) $60 \%$ of the web pages on the internet in 2002 were in the English language. Concerns arise in the twenty first century therefore that identities around the world are being increasingly consolidated around English speaking, largely American, western cultural and linguistic norms. One consequence of this is seen as being the demise of minority language at an unprecedented scale. Krauss (1992) argues that over the last century half of the worlds 6000 languages have become moribund- that is spoken by adults who are not passing it on. Another $40 \%$ are in decline so $90 \%$ of the worlds languages are in danger of disappearing Such conclusions about the worlds languages have also been reached by Brenzinger (1992) and Schmidt (Coupland, et al., 2005). According to Coupland et al. (2005) however over the last ten years...

Welsh provides a rare instance of sustained minority language revival. There is consensus in government, the press, popular discourse, education and academic circles in Wales, that Welsh is being revitalised at present. (p. 1)

McCrone and Kiely (2000) argue that such findings makes sense because as globalisation has advanced it has had the effect of eroding the doctrine of national sovereignty and as a result power and jurisdictions have become layered. Increasingly, they argue, people have come to identify with these different layers so that nation-states face a crisis of the hyphen (Anderson, 1983) whilst pan-national and ethnic affiliations grow stronger. Melucci (1996) also suggests that globalisation and pan-national political organisation has served to reactivate local ethnic identities as people seek to give a stable and recognisable basis to their identity. In the Uk Hall (2000) argues that a growing sense of interest has been developing in Celtic and English national identity as distinct from the British national identity. For example, he notes how the use of the English flag (the cross of St. 
George), has become a popular sight, especially at sports events where once the Union flag would have been flown. As Britain has waned as a political and economic entity, there is resurgence in Celtic identities and English nationalism particularly among the young. According to Harris (2006) and Coupland et al. (2006) since the turn of the century and on the back of the construction of a new rugby arena for the Welsh rugby team in Wales, the success of Welsh popular music bands and the move towards devolution, a new more confident Welsh ethnic identity is beginning to express itself. Coupland et al. (2006) suggests that as part of this, speaking Welsh and being Welsh is now considered fashionable amongst the young when previously it was not, and not having opportunities to perform the Welsh identity becomes increasingly problematic.

\section{CONCLUSION}

Provisions for indigenous languages are now endorsed in a number of morally or legally binding International, European and national declarations. At the international level, The Universal Declaration of Human Rights, The International Covenant on Civil and Political Rights, The Rights of Person's Belonging to National, Ethnic, Religious and Linguistic Minorities all, in some way, address the issue of respecting the linguistic human rights (www.un.org). Within the European Union, The European Convention for the Protection of Human Rights and Fundamental Freedoms, The Framework Convention for the Protection of National Minorities and the European Charter for Regional or Minority Languages also place expectations on member states in terms of respecting language minorities within their territories. In 2006 however the Council of Europe watchdog committee overseeing implementation of the European Charter for Regional and Minority Languages, argued the UK Government must do more to meet its obligations to protect minority languages in the UK. An important part of this activity could be bringing political influence to bare on organisations such as ICASNN that has control over some of the micro processes through which individuals and groups affirm their identity and language. According to May (2000) an issue that must be addressed when promoting a minority language is how can a minority language be legitimated and institutionalised in the public or civic realm. Establishing a .cym TLD might play a part in such a process of legitimisation and institutionalisation.

In its policy statements ICANN argues that it does not create or make internet policy. "Rather, policy is created through a bottom up transparent process involving all necessary constituencies and stakeholders in the internet community" (www.icann .org). Whilst a laudable claim, this is problematic because it does not ensure that the voices of minorities rise to the same extent as those of the majority. By adopting the view that only those countries identified under ISO-3166-1 may be allocated a cc-TLD, ICANN has effectively ensured some minorities find themselves located within a cc-TLD which they experience as oppressive.

New g-TLD have been slow to develop because it has been argued a new g-TLD must be supported by enough users to make its establishment viable. A g-TLD for Wales may very well be viable conceived as a resource for all the people of Wales. In 2002 Welsh language speakers and
Welsh people represented a considerable proportion of internet users. According to Guinovart (2003) the Welsh language was the fourty-second most popular internet language. Whilst the Welsh language is spoken by around $21 . \%$ of the population of Wales (550,000 people), around 2.5 million people live in Wales and a significant proportion might make some claim to Welsh heritage and cultural affiliations. Hence a provision such as g-TLD for wales would target a sizeable potential population, and at least a population as big as served by some cc-TLD's. Statistics aside however, moral arguments have been outlined that set the context for assertive and positive micro actions that may contribute to saving minority languages and marginalised cultures in an increasingly globalised and English language dominated world.

\section{AKNOWLEDGEMENT}

Iolo Madoc-Jones is Principal Lecturer in Social Care at the North East Wales Institute. Prior to this he worked as a Probation Officer. He has published widely on the issues of language and IT in such journals as the British Journal of Community Justice and British Journal of Social Work.

\section{BIBLIOGRAPHY}

Alcoff, L.M. (1997). Philosophy and radical identity. Philosophy 41, 67-76. Anastasi, A., \& Cordova, F.A. (1953). Some effects of bilingualism upon intelligence test performance of puerto rican children in New York city. Journal of Educational Psychology 44, 1-19.

Anderson, B. (1983). Imagined communities. Verso, London.

Atkinson, D. (2006). Catalan on the internet and the .ct and .cat campaigns. Journal of Language and Politics 5(2), 239-249.

Ball, M. (1993). The Celtic languages. Routledge, London.

Barth, F. (1969). Ethnic Groups and Boundaries. Long Grove, Illinois, USA: Waveland Press Ltd.

Biling, M. (1995). Banal Nationalism. London: Sage.

Bishop, H., Coupland, N., \& Garrett, P. (2003). Blood is thicker than the water that separates us-dimensions and qualities of Welsh identity in the North American diaspora. North American journal of Welsh studies 3(2), 37-52.

Blackledge, A., \& Pavlenko, A. (2001). Negotiation of identities in multilingual contexts. The International Journal of Bilingualism 5(3), 243-257.

Blackledge, A. (2002). What sort of people can look at a chicken and think dofednod? Language, Ideology and Nationalism in public discourse. Multilingua 21, 197-226.

Bleiker, R. (2001). The Aesthetic turn in international political theory. Millennium 30(3), 509-534.

Bossard, J.H.S. (1945). The bilingual as a person-linguistic identification with status. American Sociological Review 10, 699-709.

Borland, J., Fevre, R., \& Denny, D. (1992). Nationalism and Community in North West Wales. The Socioloigal Review 14(1), 49-72.

Bourdieu, P. (1977). Outline of a theory of practice. Cambridge: Cambridge University Press.

Bourdieu, P. (1977). The economy of linguistic exchanges. Social Science Information 16, 645-668.

Bourdieu, P. (1991). Language \& Symbolic Power. Harvard University Press.

Brezinger, M. (1992). Language death: Factual and theoretical explorations with reference to East Africa. Berlin. Mouton de Gruyter.

Brown, W. (1995). States of injury: Power and freedom in late modernity. Princeton: Princeton University Press.

Burr, V. (1995). An introduction to social constructionism. London: Routledge. Bwrdd yr Iaith Beaufort report. The state of the Welsh language. Welsh language Board. 2000. Available from: www.bwrdd-yr-iaith.org.uk [Accessed 2007, Aug. 1].

Commissioners of Inquiry into the State of Education in Wales (1847) Part II. Brecknock, Cardigan, Radnor, and Monmouth, London (871 XXVII), London. Great Britain. Parliament Sessional Papers 1847.

Connolly, W. (2002). Identity/ difference: Democratic Negotiations of Political Paradox. Minneapolis: University of Minnesota press. 
Coupland, N., Bishop, H., Evans, B., \& Garrett, P. (2005). Imagining Wales and the Welsh language: Ethnolinguistic subjectivities and semographic flow. Journal of Language and Social Psychology 25(4), 351-376.

Coupland, N., Bishop, H., Williams, A., Evans, B., \& Garrett, P. (2005). Affiliation, engagement, language use and vitality: Secondary school student's subjective orientations to Welsh and Welshness. The International Journal of Bilingual Education and Bilingualism 8(1), 1-23.

Coupland, N., Bishop, H., Evans, B., \& Garrett, P. (2006). Imagining Wales and the Welsh language: Ethnographic subjectivities and demographic flow. Journal of Language and Social Psychology 25(4), 351-376.

Crystal, D. (2000). The Cambridge encyclopaedia oflanguage. Cambridge: Cambridge University Press.

Davies, J. (1994). The welsh language. University of Wales, Bangor.

Drakeford, M., \& Williams, C. (2001). Social work in Wales. In M.Payne, \& S.M. Shardlow, (Eds.), Social work in the British Isles (pp. 156184). London, Jessica Kingsley Publishers.

Dunbar, R. (1996). Grooming, Gossip, and the evolution of language. Cambridge MA: Harvard University Press.

Edwards, J. (1994). Multilingualism. London: Routledge.

Edwards, J. (2001). The ecology of language revival. Current issues in language planning 2(2\&3), 231-241.

Fishman, J.A. (2000). The new linguistic order. In P. O'Meara, H.D. Mehlinger, \& M. Krain, (Eds.). Globalisation and the challenges of a new century: A reader (pp. 435-442). Bloomington, Indiana University Press.

Fishman, J. (1997). Language and ethnicity: The view from within. In F. Coulmas, (Ed.), The handbook of sociolinguistics. London: Blackwell.

Gellner, E. (1983). Nations and Nationalism. Oxford: Blackwell.

Gerrand, P. (2006). Cultural diversity in cyberspace: The Catalan campaign to win the new .cat top level domain. First Monday. 11(1). Available at: http://www.firstmonday.org/issues/issue11_1/gerrand/index.html [Accessed 2008, June 24].

Giles, H., Bourhis, Y. \& Taylor, M. (1977). Towards a theory of ethnic group relations. In $\mathrm{H}$. Giles, (Ed.), Language, ethnicity and intergroup relations (pp. 307-344). London: Academic Press.

Griffiths, A. (1994). Ethnography and popular memory: postmodern configurations of Welsh identities. The Australian Journal of Media \& Culture 7(2), 307-326.

Guinovart, X.G. (2003). A lingua galega en internet. In A. Bringas, \& B. Martin, (Eds.), Nacionalismo e Globalizacion: Lingua Cultura e Identidade (pp. 71-88). University of Vigo: Spain.

Hall, J.A. (2000). Globalization and Nationalism. Theses Eleven 63, 63-79.

Harris, J. (2006). (Re) Presenting Wales; national identity and celebrity in the post-modern rugby World. North American Journal of Welsh Studies 6(2), 1-13.

Hechter, M. (1975). Internal colonisation: The celtic fringe in british national development 1536-1966. London: Routledge and Keegan Paul.

Heller, M.S. (1982). Negotiations of language choice in Montreal. In J.J. Gumperz, (Ed.), Language and Social Identity. Cambridge: Cambridge University Press.

Heller, M.S. (1982). Language choice, social institutions and symbolic domination. Language in Society 24, 373-405.

Hobsbawm, E., \& Ranger, T. (1993). The invention of tradition. Cambridge: Camnbridge University Press.

Hourigan, N. (2001). New social movement theory and minority television campaigns. European Journal of Communication 16(1), 77-100.

Howe, D. (1994). Modernity, Postmodernity and social work. British Journal of Social Work 5, 513-32.

Jackson, K. (1994). Language and history in early Britain. Four courts press. Oxford.

Jenkins, G.H. (1997). The welsh language before the industrial revolution. Cardiff, UK: University of Wales Press.

Jobins, S. (2006). Beyond frontiers. Agenda. Summer, 59-61.
Kachru, B. (1996). The paradigms of marginality. World Englishes 15(3), 241-255.

Kedourie, E. (1960). Nationalisms. London. Huchinsons.

Kidd, W. (2002). Culture and identity. Palgrave: Basingstoke.

Krauss, M. (1992). The World's languages in crisis. Language 68, 6-10.

Krauss, M. (1995). Language loss in Alaska, the United States and the world. Alaska Humanities Forum 6(1), 2-5.

Kymlicka, W., \& Patten, A.A. (2003). Language rights and political theory. Oxford: Oxford University Press.

Marwick, A. (1996). British society since 1945 ( $3^{\text {rd }}$ ed.). London: Penguin.

Matonis, A.T.E., \& Melia, D.F. (1990). Celtic Language, Celtic Culture: A Festschrift for Eric P. Hamp.California: Van Nuys, Ford \& Bailie.

May, S. (2001). Language and Minority Rights: Ethnicity, Nationalism and The politics of language. Pearson, Essex.

May, S. (2001). Language and minority rights: Ethnicity, Nationalism and the politics of language. Pearson, Essex, UK.

McCrone, D., \& Kiely, R. (2000). Nationalism and citizenship. Sociology 34(1), 19-34.

Melucci, A. (1996). Challenging codes: Collective action in the information age. Cambridge University Press. Cambridge.

Mill, J.S. (1972). Considerations on representative governemnt. In $\mathrm{H}$. Acton, (Ed.), London: J.M. Dent (original 1861).

Nelde, P. (2000).Prerequisites for a new European language policy. Journal of Multi-Lingual and Multi-Cultural Development 21(5), 442-450.

Pugh, R., \& Jones, E. (1999). Language and practice: Minority language provision within the guardian ad litum service. British Journal of Social Work 29(4), 529-45.

Renan, E. (1990). What is a Nation? In H. Bhabha, (Ed.), Nation and Narration (pp. 8-22). London. Routledge.

Rex, J. (1996). National identity in a democratic multi-cultural state. Sociological research Online. 1(2), http:/www.socresonline.org.uk/ socresonline/1/2/1.html

Robbins, K. (2001). More than a footnote? Wales in British history. North American Journal of Welsh studies 1(1), 20-24.

Russell, P. (1995). An Introduction to the Celtic languages. Longman, London.

Sapir, E. (1929). The status of linguistics as a Science. Language 5, 207214.

Schmidt, A. (1990). The Loss of Australia's Aboriginal Language Heritage. Canberra. Aboriginal Studies Press.

Smith, M. (1939). Some light on the problem of bilingualism as found from a study of the progress in mastery of English among preschool children of Non-American ancestry in Hawaii. Genetic Psychology Monograph 21, 121-284.

Spoerl, D. (1943). Bilingual and emotional adjustment. Journal of Abnormal and Social Psychology 33, 37-57.

Trevor-Roper, H. (1983). The invention of tradition: The highland tradition of Scotland. In E. Hobsbawm, \& T. Ranger, (Eds.), The invention of tradition (pp. 15-41). Cambridge Uk. Cambridge University press.

Vygotsky, L.S. (1962). Language and ideology. Cambridge, Mass: MIT Press.

WAG. Iaith pawb and Welsh language scheme annual report 2005-2006. (2006) Cardiff: Welsh Assembly Government.

Whorf, B.L. (1956). Language, Thought and reality: Selected writings of Benjamin Lee Whorf. Cambridge, Mass: MIT Press.

Williams, C. (1999). Passports to Wales? Race, nation and indentity. In R. Fevre, \& A. Thompson, (Eds.), Nation, Identity and Social Theory (pp. 69-90). University of Wales Press LLandybie.

Williams, C. (1999). Governance and the language. Contemporary Wales $12,130-154$

Williams, G.A. (1985). When Was Wales. London: Penguin.

Woodward, K. (2002). Identity and Difference. London, Sage.

Worsley, P. (1984). The three worlds: Culture and World Development. London: Weidenfeld and Nicholson.

Yoshioka, J.G. (1929). A Study of bilingualism. Journal of Genetic Psychology 36, 473-479.

CIolo Madoc-Jones; Licensee Bentham Open.

This is an open access article licensed under the terms of the Creative Commons Attribution Non-Commercial License (http://creativecommons.org/licenses/by-nc/3.0/) which permits unrestricted, non-commercial use, distribution and reproduction in any medium, provided the work is properly cited. 